\title{
In Memoriam Miss Joan H. Van Thal
}

\section{M.B.E., F.C.S.T., L.R.A.M.}

Joan Van Thai was born in Rotterdam in 1900 and died on February 9th 1970 in retirement in Cornwall. Her mother was Dutch and her father British. She came to England to live at 11 years of age. She was always frail and suffered from poor sight. She wanted to study medicine but this was not allowed on account of her eye-sight and instead she studied dispensing and in 1918 took up work at St. Thomas's Hospital, London. Here she met Elsie Fogerty, Principal of the Central School of Speech and Drama (then located in the Albert Hall), who was in charge of remedial speech training at St. Thomas's for cleft palate children and stammers. Elsie Fogerty interested Joan Van Thai in this work and persuaded her to enrol as a student at the Central School in 1919. She studied speech and drama and developed a beautiful voice and considerable skills in acting but specialised in remedial speech to which in fact she was to dedicate her life.

In 1924 Joan Van Thai was appointed to the staff of the Central School as a lecturer and worked as an assistant in St. Thomas's speech clinic. In 1942 she became Head of the Speech Therapy Department of the Central School, where she remained until 1960. She held appointments also at the Royal Dental Hospital (1922-1962), the Eastman Dental Hospital, where she was a lecturer to post graduate dental students, St. Thomas's Hospital (1924-1950) and St. Bartholomew's Hospital (1947-1963). She published a practical little book, «Cleft Palate» in 1934 and «Elements of Logopedics: a handbook for students of speech therapy» in 1969. The latter work shows how severely handicapped she had been academically for many years through inability to read and keep pace with scientific developments in speech pathology. In the years between she published many articles in British Journals besides 'Folia Phoniatrica' - her chief interest being dysphonia.

Joan Van Thai will be remembered most for her remarkable organising ability and dedication to the promotion of speech therapy services in England and Europe. Her services to the profession were

450

\section{In Memoriam}

recognised in 1950 when she was awarded the M.B.E. She was active in uniting the Association of Speech Therapists with the British Society of Speech Therapists between 1934-1942 and became the first Chairman of the Organising Committee of the Association of Speech Therapists in 1942. In 1943 the College of Speech Therapists was founded and Joan Van Thai among others a Founder Fellow of the College. She was to be elected Chairman of the College many times and served on all its Committees and the Examination Board. She took a keen interest in the syllabus for the Licentiate Diploma of the College and in student training. She had a prodigious memory and could remember with accuracy details of College Council meetings and College affairs for many years back and was a mine of information and wisdom besides being an indefatigable worker and architect during the formative years of the College of Speech Therapists. Joan Van ThaГs interests and ambitions were not confined to the British scene and her Dutch connections drew her early into international logopedics and phoniatrics while her compatriots 
remained peculiarly insular. She was a gifted linguist and besides Dutch and English spoke fluent French and German and latterly acquired Italian and Spanish. She was unique among her British contemporaries in this alone. Her Dutch cousin Branco Van Dantzig, a distinguished logopedist, took her to meetings and clinics in Europe. In 1926 she attended the 2nd Congress of the International Association of Logopedics and Phoniatrics and in 1930 a Summer Course in Vienna where she participated with the Viennese group: Froeschels, Stein, Trojan, Weiss, Jellínek and many others. Her delightful gaiety, animation and zest in those pre-war, care-free years are still remembered by her friends. In 1936 she was elected to the Board of I.A.L.P. and in 1950 became a Vice-President. She attended every international congress of I.A.L.P. and kept in touch with members between congresses and was a helpful and active adviser on International and British Logo-pedic matters. In 1956 she became general secretary to I.A.L.P. and during the next three years was busy organising the very successful London Congress of 1959 to which American speech pathologists came in numbers for the first time. Her knowledge of languages was an immense asset in this organisation. She was elected President of I.A.L.P. in 1959 and completed one 3 year term of office but had to relinquish this office at the height of her career on account of her now rapidly deteriorating sight. During her tenure of office her organising and administrative ability were effectively employed in introducing

In Memoriam

451

a more democratic system of election of officers, in clarifying rules and in improving regulations and relations between the constituent national representatives of the Association.

Joan Van Thai will be remembered by those who knew her for hervivid personality her keen intelligence and wit her indomitablecourage and valiant spirit which transcended physical handicap.Posterity will remember her as the most outstanding of the firstBritish Speech Therapists who fought to establish a profession ofspeech therapy in its own right. Margaret Greene

F.C.S.T

London 